\title{
The Concept of the Right to Cultural Heritage within the Faro Convention
}

\author{
Ondřej Vícha ${ }^{1}$
}

\section{Faculty of Law, Palacký University Olomouc, Czech Republic email: ondrej.vicha@upol.cz}

VÍCHA, Ondřej. The Concept of the Right to Cultural Heritage within the Faro Convention. International and Comparative Law Review, 2014, Vol. 14., No. 2, pp. 25-40. DOI: 10.1515/iclr-2016-0049.

\begin{abstract}
The paper deals with the protection of cultural heritage and defines its value to society within the Faro Convention, which was adopted by the Council of Europe in 2005. Author is focuses on the innovative concept of the "common heritage of Europe" and its relationship to human rights and fundamental freedoms. The paper addresses the right to cultural heritage which is within the Faro Convention expressed as a dimension of the right to participate in the cultural life of the community and the right to education. In this context, the paper refers to other international human rights documents, such as the Universal Declaration of Human Rights or the International Covenant on Economic, Social and Cultural Rights. The paper also presents other individual principles and provisions of the Faro Convention regarding organisation of public responsibilities for cultural heritage or access to cultural heritage and democratic participation.
\end{abstract}

Keywords: cultural heritage, human rights, right to participate in cultural life, right to education, Council of Europe, Faro Convention

\section{Introduction}

Europe's cultural heritage, both tangible and intangible, is our common wealth - our inheritance from previous generations of Europeans and our legacy for those to come. It is an irreplaceable repository of knowledge and a valuable resource for economic growth, employment and social cohesion. It enriches the individual lives of hundreds of millions of people, is a source of inspiration for thinkers and artists, and a driver for our cultural and creative industries. Our cultural heritage and the way we preserve and valorise it is a major factor in defining Europe's place in the world and its attractiveness as a place to live, work, and visit. ${ }^{2}$

Cultural heritage is perceived as a shared resource, and a common good. Like other such goods it can be vulnerable to over-exploitation and under-funding,

1 Department of Administrative Law and Finacial Law, Faculty of Law, Palacký University Olomouc, Czech Republic.

2 Communication from the Commission to the European Parliament, the Council, the European Economic and Social Committee and the Committee of the Regions - Towards an integrated approach to cultural heritage for Europe, $\operatorname{COM}(2014) 477$ final, p. 2. 
which can result in neglect, decay and, in some cases, oblivion. Looking after our cultural heritage is, therefore, our common responsibility. Cultural heritage protection is primarily a matter for national, regional and local authorities. However, international cooperation in this field is now increasingly developing as a result of the devastating effects of armed conflicts, in which significant part of the cultural heritage was damaged.

\section{The Council of Europe and cultural heritage}

One of the most important international organizations concerned with the protection of cultural heritage at the government level, is the Council of Europe. ${ }^{3}$

This international organization was founded in 1949 and its headquarters is located in Strasbourg. It includes 47 member states, 28 of which are members of the European Union. All Council of Europe member states have signed up to the Convention for the Protection of Human Rights and Fundamental Freedoms (Rome, 1950), ${ }^{4}$ a treaty designed to protect human rights, democracy and the rule of law. Apart from guaranteeing these rights and democracy (through reforms) members of the Council of Europe also cooperate in the fields of environment, ${ }^{5}$ culture and education.

Framework for the Council of Europe in the field of culture heritage creates the European Cultural Convention (Paris, 1954). ${ }^{6}$ Each contracting party shall take appropriate measures to safeguard and to encourage the development of its national contribution to the common cultural heritage of Europe. ${ }^{7}$ Each contracting party shall, insofar as may be possible, encourage the study by its own nationals of the languages, history and civilisation of the other contracting parties and grant facilities to those parties to promote such studies in its territory, and endeavour to promote the study of its language or languages, history and civilisation in the territory of the other contracting parties and grant facilities to the nationals of those parties to pursue such studies in its territory. ${ }^{8}$ Each contracting party shall regard the objects of European cultural value placed under its

3 See http://www.coe.int.

4 The current state of signatures and ratifications of the Convention and its Protocols as well as the complete list of declarations and reservations are available at http://www.conventions.coe.int, or see e.g. MARINGELE, Sarah. European Human Law Rights. The work of European Court of Human Rights illustrated by an assortment of selected cases. Hamburg: Anchor Academic Publishing, 2014.

5 ZÁSTĚROVÁ, Jana: Ochrana životního prostředí v činnosti Rady Evropy. [Environmental protection in the activities of the Council of Europe]. České právo životního prostředí, 2001, roč. I, č. 1, s. $45-51$.

6 For the Czech Republic, the Convention entered into force on 10 May 1990. See Communication of the Federal Ministry of the Foreign Affairs No. 290/1990 Coll.

7 Art. 1 of the European Cultural Convention.

8 Art. 2 of the European Cultural Convention. 
control as integral parts of the common cultural heritage of Europe, take appropriate measures to safeguard them and ensure reasonable access thereto. ${ }^{9}$

The Council of Europe action in the field of cultural and natural heritage includes promoting diversity and dialogue through access to heritage to foster a sense of identity, collective memory and mutual understanding within and between communities, and contributing to development that is linked to territorial cohesion, life style and relationships through the notion of heritage and landscape as community resources. This work involves the follow-up of Council of Europe conventions on heritage and landscape, including the targeting of decision-makers, professionals and civil society. Different forms of co-operation include the systematic exchange of information, reviews of policies, the development of prospective thinking in the sector of cultural and natural heritage, and technical assistance programmes and field work. The work is carried out under the guidance of the Steering Committee for Cultural Heritage and Landscape (CDPATEP) in line with the principles for sustainable territorial development promoted by the Conference of the Council of European Ministers responsible for landscape development (CEMAT).

In the field of cultural heritage, the Council of Europe adopted a number of international treaties. These include the Convention on the Protection of the Architectural Heritage of Europe (Granada, 1985), ${ }^{10}$ the European Convention for the Protection of the Archaeological Heritage (Revised) (Valetta, 1992), ${ }^{11}$ the European Landscape Convention (Florence, 2000) ${ }^{12}$ and the European Convention for the Protection of the Audiovisual Heritage (Strasbourg, 2001).

\section{The Faro Convention}

European societies, being transformed under the combined effects of the economic crisis, energy transition, demographic or migration factors and a reduction in resources, call for new development models driven by greater democracy, strengthened citizen participation and better governance based on more open, reactive and transparent institutions. In this context, the Framework Convention on the Value of Cultural Heritage for Society was adopted by the Committee of Ministers of the Council of Europe on 13 October 2005, and opened for signa-

9 Art. 5 of the European Cultural Convention.

10 In the Czech Republic, published in the Collection of International Treaties under No. $73 / 2000$ Coll.

11 In the Czech Republic, published in the Collection of International Treaties under No. 99/2000 Coll.

12 In the Czech Republic, published in the Collection of International Treaties under No. 13/2005 Coll. See Landscape and sustainable development: challenges of the European Landscape Convention. Strasbourg: Council of Europe Publishing. 2006 or KYSELKA, Igor.: Co pro nás vyplývá z přijetí Evropské úmluvy o krajině? [What follows for us from the adoption of the European Landscape Convention?]. Urbanismus a územní rozvoj č. 3/2001. s. 25 32 . 
ture to member states in Faro (Portugal) on 27 October 2005. The Faro Convention entered into force on 1 June 2011.

The Faro Convention is innovative in linking the concept of the common heritage of Europe to human rights and fundamental freedoms for which the Council of Europe remains one of the historic guardians. The Faro Convention provides an original contribution to the issues related to living together, quality of life and the living environments where citizens wish to prosper.

The Faro Convention is consistent with new trends which underline the growing importance of cultural values in the environment, the territorial identity, the character of landscape and the environmental dimensions of cultural heritage. This specificity clearly distinguishes the Faro Convention from earlier international instruments of the Council of Europe and from those launched by UNESCO. ${ }^{13}$ It provides the basis for the concept of a cultural environment.

To date, 17 member states ratified Faro Convention, ${ }^{14} 5$ states signed it $^{15}$ and the signing process is underway in a number of other member states of the Council of Europe ${ }^{16}$ During its plenary meeting on 27 - 29 May 2013, the Steering Committee for Culture, Heritage and Landscape (CDCPP) adopted the Faro Action Plan ${ }^{17}$ which started a series of actions aimed at promoting the Faro Convention in order to increase the number of ratifications and to ensure the implementation of the Convention's principles.

\section{a) The Right to Cultural Heritage}

Human rights are patterns of human behavior that is best in the long-term human existence on the basis of proven experience and needs as patterns of human behavior within a group - society. ${ }^{18}$ Human rights and freedoms belong to every individual, regardless of which state they are citizens. Human rights do

13 Among international conventions adopted by UNESCO in the field of cultural heritage are the Convention for the Protection of Cultural Property in the Event of Armed Conflict (The Hague, 1954), the Convention on the Means of Prohibiting and Preventing the Illicit Import, Export and Transfer of Ownership of Cultural Property (Paris, 1970), the Convention on Protection of the World Cultural and Natural Heritage (Paris, 1972), the Convention on the Protection of Underwater Cultural Heritage (Paris, 2001) and the Convention on the Conservation of Intangible Cultural Heritage (Paris, 2003).

14 Armenia, Austria, Bosnia and Herzegovina, Croatia, Georgia, Hungary, Latvia, Luxembourg, the Republic of Moldova, Montenegro, Norway, Portugal, Serbia, Slovakia, Slovenia, Ukraine and "the former Yugoslav Republic of Macedonia".

15 Albania, Belgium, Bulgaria, Italy and San Marino.

16 E.g. in Bulgaria or in Finland.

17 Available on http://www.coe.int/t/dg4/cultureheritage/heritage/Identities/AT-2014-510-Faro-AP_en.pdf.

18 BLAHOŽ, Josef. Pojem lidských a občanských práv. [The concept of civil and human rights]. In BLAHOŽ, Josef, BALAŠ, Vladimír, KLÍMA, Karel. Ústavní srovnávací právo. 4. vydání. Praha: Wolters Kluwer Česká republika, 2011, s. 177 - 178. 
not arise from the position of a person as a citizen, but from the nature of human existence.

The Faro Convention presents the right to cultural heritage as the ability to be involved with the heritage, helping to enrich it or add to it, and also to benefit from activities linked to it. The parties to the Faro Convention recognise that everyone, alone or collectively, has the right to benefit from the cultural heritage and to contribute towards its enrichment. ${ }^{19}$ Everyone, alone or collectively, has the responsibility to respect the cultural heritage of others as much as their own heritage, and consequently the common heritage of Europe..$^{20}$ Exercise of the right to cultural heritage may be subject only to those restrictions which are necessary in a democratic society for the protection of the public interest and the rights and freedoms of others. ${ }^{21}$

Although not explicitly stated in the Faro Convention, it must be understood that the right to participate also includes the right not to participate. But nonparticipation must be the result of choice and not dictated by economic, social or political circumstances.

The Faro Convention addresses the right to cultural heritage which it expresses as a dimension of the right to participate in the cultural life of the community and the right to education. In this context, the Faro Convention refers to other international human rights documents, such as the Universal Declaration of Human Rights (Paris, 1948) ${ }^{22}$ or the International Covenant on Economic, Social and Cultural Rights (New York, 1966). ${ }^{23}$

The parties to the Faro Convention agree to recognise that rights relating to cultural heritage are inherent in the right to participate in cultural life, as defined in the Universal Declaration of Human Rights. ${ }^{24}$ Under this declaraction, eve-

19 Art. 4a) of the Faro Convention.

20 Art. 4b) of the Faro Convention.

21 Art. 4c) of the Faro Convention.

22 The Universal Declaration of Human Rights (UDHR) is a milestone document in the history of human rights. Drafted by representatives with different legal and cultural backgrounds from all regions of the world, the Declaration was proclaimed by the United Nations General Assembly in Paris on 10 December 1948 as a common standard of achievements for all peoples and all nations. It sets out, for the first time, fundamental human rights to be universally protected.

23 The International Covenant on Economic, Social and Cultural Rights (ICESCR) is a multilateral treaty adopted by the United Nations General Assembly on 16 December 1966, and in force from 3 January 1976. It commits its parties to work toward the granting of economic, social, and cultural rights (ESCR) to the Non-Self-Governing and Trust Territories and individuals, including labour rights and the right to health, the right to education, and the right to an adequate standard of living. See e.g. ALSTON, Philip, QUINN, Gerard: The Nature and Scope of States Parties' Obligations under the International Covenant on Economic, Social and Cultural Rights. Human Rights Quarterly, Vol. 9, No. 2, May, 1987, pp. $156-229$.

24 Art. 1a) of the Faro Convention. 
ryone has the right freely to participate in the cultural life of the community, to enjoy the arts and to share in scientific advancement and its benefits. ${ }^{25}$

The states parties to the International Covenant on Economic, Social and Cultural Rights (ICESCR) recognize the right of everyone to take part in cultural life. $^{26}$ The steps to be taken by the states parties to the ICESCR to achieve the full realization of this right shall include those necessary for the conservation, the development and the diffusion of science and culture. ${ }^{27}$ The states parties to the ICESCR recognize the benefits to be derived from the encouragement and development of international contacts and co-operation in the scientific and cultural fields. ${ }^{28}$

As regards the second component of the right to cultural heritage, the right to education, this right belongs to everyone under the Universal Declaration of Human Rights (UDHR). ${ }^{29}$ Education shall be directed to the full development of the human personality and to the strengthening of respect for human rights and fundamental freedoms. It shall promote understanding, tolerance and friendship among all nations, racial or religious groups, and shall further develop the activities of the United Nations for the maintenance of peace. ${ }^{30}$ Parents have a prior right to choose the kind of education that shall be given to their children. ${ }^{31}$

Similarly, the right to education is recognized by the states parties to the International Covenant on Economic, Social and Cultural Rights (ICESCR). They agree that education shall be directed to the full development of the human personality and the sense of its dignity, and shall strengthen the respect for human rights and fundamental freedoms. They further agree that education shall enable all persons to participate effectively in a free society, promote understanding, tolerance and friendship among all nations and all racial, ethnic or religious groups, and further the activities of the United Nations for the maintenance of peace. ${ }^{32}$

The Faro Convention expressly provides that none of its provisions shall be interpreted so as to limit or undermine the human rights and fundamental freedoms which may be safeguarded by international instruments, in particular, the Universal Declaration of Human Rights (UDHR) and the Convention for the Protection of Human Rights and Fundamental Freedoms.

25 Art. 27 par. 1 of the Universal Declaration of Human Rights.

26 Art. 15 par. 1a) of the International Covenant on Economic, Social and Cultural Rights.

27 Art. 15 par. 2 of the International Covenant on Economic, Social and Cultural Rights.

28 Art. 15 par. 4 of the International Covenant on Economic, Social and Cultural Rights.

29 Art. 26 par. 1 of the Universal Declaration of Human Rights.

30 Art. 26 par. 2 of the Universal Declaration of Human Rights.

31 Art. 26 par. 3 of the Universal Declaration of Human Rights.

32 Art. 13 par. 1 of the International Covenant on Economic, Social and Cultural Rights. 


\section{b) Common Heritage of Europe}

The Faro Convention's aim of addressing the cultural heritage of Europe in its wider social context is expressed by the introduction of the idea of common heritage of Europe, composed of two inseparable elements:

- the cultural heritage, which represents a resource and a source of collective memory for people in Europe, and;

- the shared intellectual heritage of an agreed set of social values, rooted in history, which form the European ideal in terms of how society should operate.

The mutually-supporting interaction of these two elements constitutes a unifying theme of the Faro Convention, developing the important principles of the Declaration on Intercultural Dialogue and Conflict Prevention (Opatija, 2003) ${ }^{33}$, of respect and fair treatment for "cultural identities and practices and the expression of the corresponding forms of heritage, provided that these comply with the principles upheld by the Council of Europe“.

In accordance with the concept of the common heritage of Europe, constituted essentially through shared experience and commitment to human rights and democratic principles, the Faro Convention deals with heritage as an object of individual rights which give it meaning. This avoids the uncertainty of changing definitions of heritages, by referring to their foundation in human rights and liberties. ${ }^{34}$ In the Faro Convention, heritage is treated both as a source ${ }^{35}$ and as a resource for the exercise of freedoms. ${ }^{36}$

The Faro Convention ${ }^{37}$ develops the idea of a common heritage of Europe in which the cultural heritage shared by Europeans interacts with the agreed democratic, political and social ideals of Europe to generate the idea of a common European responsibility towards cultural heritage. This corresponds to the distinctive character of the European heritage resulting from its depth and rich historical stratification, its diversity of regions and shared cultural phenomena, the products of the interaction of diverse cultures over the centuries.

33 Adopted by the European ministers responsible for Cultural Affairs in Opatija (Croatia) on 22 October 2003.

34 Art. 4 of the Faro Convention exactly follows the logic of interpretation of the European Convention on Human Rights.

35 Preamble, par. 1 of the Faro Convention.

36 Preamble, par. 3 and art. 2 of the Faro Convention.

37 Article 3 of the Faro Convention reads: „The Parties agree to promote an understanding of the common heritage of Europe, which consists of:

a all forms of cultural heritage in Europe which together constitute a shared source of remembrance, understanding, identity, cohesion and creativity, and

$b \quad$ the ideals, principles and values, derived from the experience gained through progress and past conflicts, which foster the development of a peaceful and stable society, founded on respect for human rights, democracy and the rule of law.. 
Thus defined, the European cultural heritage is a primary resource for democratic engagement in support of cultural diversity and sustainable development; by the same token, it is a source of prosperity and of unity for the diverse communities present in Europe. Europe's cultural heritage is treated in the Faro Convention as the cultural capital from which, through the investment of human ingenuity and effort, originate the rich and varied cultures of modern Europe. Conservation of this cultural capital is essential, both for its intrinsic value and its potential as an investment from which future development - cultural, social and economic - may be generated.

\section{c) Cultural Heritage}

The definition of cultural heritage is the broadest proposed by any international instrument to date. It pays particular attention to the interactive nature of the cultural heritage, recognising that it is defined and redefined by human actions and that it must not be perceived as either static or immutable. For the purposes of the Faro Convention, cultural heritage is a group of resources inherited from the past which people identify, independently of ownership, as a reflection and expression of their constantly evolving values, beliefs, knowledge and traditions. It includes all aspects of the environment resulting from the interaction between people and places through time. ${ }^{38}$

This definition draws particular attention to the environmental dimension, recognising the inseparability of human and natural influences in landscape and also the inherited context of cultural environment. It thus goes beyond the concept of historic environment, which tends to be concerned mainly with tangible aspects of the inherited environment.

It is important to note the reference to ownership: the fact that an item is regarded as the cultural heritage of one or more communities or interest groups does not negate private proprietorial status. However, limitations in the exercise of private rights may be justified in the public interest, in proportion to the values placed upon particular items. ${ }^{39}$

\section{d) Heritage Communitties}

The idea of the common heritage of Europe allows an approach to the notion of heritage communities, for which can be no cultural life without a community. ${ }^{40}$ A heritage community is defined in the Faro Convention as a variable geometry, avoiding reference to ethnicity or other rigid communities. ${ }^{41}$ The term heritage

38 Art. 2a) of the Faro Convention.

39 See Art. 4c) and art. 5a) of the Faro Convention.

40 Art. 27 of Universal Declaration of Human Rights (UDHR).

41 Art. 2b) of the Faro Convention reads: "For the purposes of this Convention a heritage community consists of people who value specific aspects of cultural heritage which they wish, within the framework of public action, to sustain and transmit to future generations." 
communities here are therefore a very different concept from the heritage community, the term sometimes used to encompass all professionals engaged in heritage-related activities. The Faro Convention concentrates upon the benefits of developing co-operation between the diverse heritage communities which occur within Europe.

The novel reference to heritage communities signifies that heritage awareness in the future should stem not only from professional expertise but also from the aspirations of population groups which may not be linked by language, an ethnic tie or even a shared past, but are linked by a purposive commitment to specific heritages. ${ }^{42}$

This is an area which, more than any other, requires international and transnational co-operation to bring together the community of peoples represented in the Council of Europe. Consequently, the Faro Convention is distinct from the work of UNESCO, both

- in respect of cultural diversity: the field has been expanded by the Universal Declaration of UNESCO on Cultural Diversity (2001)..$^{43}$ The Faro Convention, while recognising the important synergy between cultural heritage and cultural diversity, concentrates primarily upon how the cultural heritage can be used sustainably to create economic and social conditions favourable to the survival of diverse communities. The maintenance of cultural diversity in the face of globalisation is the objective of international effort;

- in respect of tangible elements of the heritage: UNESCO's work on a global scale continues to operate by a sectoral approach, establishing lists of major assets regarded as world heritage, whereas the Faro Convention deals with cultural heritages as ensembles;

- in respect of intangible aspects of cultural heritage, where the Faro Convention focuses primarily on ascribed values rather than on the material or immaterial elements which combine to constitute heritages, thus taking an approach which is distinct from the UNESCO's Convention for the Safeguarding of the Intangible Cultural Heritage (Paris, 2003). ${ }^{44}$

\section{e) Framework Character of the Faro Convention}

A framework convention was considered the most appropriate type of instrument to develop a policy framework for a new era. Framework conventions

42 THÉROND, Daniel. Benefits and innovations of the Council of Europe Framework Convention on the Value of Cultural Heritage for Society. Heritage and Beyond. Strasbourg: Council of Europe Publishing, 2009, p. 10.

43 STENOU, Katérina (ed.). UNESCO Universal Declaration on Cultural Diversity. Cultural Diversity Series No. 1, Paris: UNESCO, 2002. Available on http://www.unseco.org/culture.

44 Text of the Convention for the Safeguarding of the Intangible Cultural Heritage is available on http://www.unesco.org/culture/ich/index.php?lg=en\&pg=00022. 
define broad objectives and identify areas for action, as well as the directions in which the contracting parties agree to progress. Legal instruments of this type may identify generic activities but, unlike ordinary conventions, do not create obligations to specific actions.

There will often be alternative means of achieving the objectives, and it is open to contracting parties to choose the route most suited to their own national traditions of law, policy and practice, always taking into account the need to ensure that their own approaches are consistent with those of neighbouring states and other parties.

A framework convention identifies the direction and the destination of an ambitious European journey, but is not a detailed route-map or timetable. The Faro Convention presents a new way of considering Europe's cultural heritage. While previous instruments have concentrated on the need to conserve that heritage, and how it should be protected, this instrument identifies a range of ways of using the cultural heritage, and concentrates upon why it should be accorded value.

\section{f) Cultural Heritage as a Public Interest}

The Faro Convention concerns the political undertakings that are necessary to permit and guarantee the exercise of the rights to heritage. There is a logic to the order of the article 5 of the Faro Convention which flow from recognising the public interest inherent in elements of the cultural heritage, through the processes of identification and understanding, leading to a policy of integration of respect for cultural heritage in all dimensions of development, with the participation of all.

The parties of the Faro Convention undertake to recognise the public interest associated with elements of the cultural heritage in accordance with their importance to society. ${ }^{45}$ It is important to set bounds to the public interest, recognising that it may conflict with private interests. A proportionality principle must be applied because everything cannot be protected. It is the responsibility of parties to define the criteria for public interest and to translate them into both the extent and the degree of protective measures that they consider necessary.

The Art. 5 of the Faro Convention develops the complex idea of valorisation, integrating a chain of actions in the public interest: identification, study, interpretation, protection, conservation and presentation. The idea of valorisation is, like cultural heritage itself, multi-dimensional: it involves giving value to the ethical, cultural, ecological, economic, social and political dimensions of a heritage. As a resource for personal and communal development, cultural heritage is an asset which requires preservation, and thus its valorisation can be considered one factor of development.

45 Art. 5a) of the Faro Convention. 
As emphasised in art. 6c), the Faro Convention does not impose directly applicable obligations, but invites parties to adopt adequate measures if existing arrangements are not sufficient.

\section{g) Contribution of Cultural Heritage to Society and Human Development}

Article 8 of the Faro Convention deals with the cultural heritage aspects of environment as a necessary resource for territorial cohesion and quality of life. The parties to the Faro Convention undertake to utilise all heritage aspects of the cultural environment to enrich the processes of economic, political, social and cultural development and land-use planning, resorting to cultural heritage impact assessments and adopting mitigation strategies where necessary, and to promote an integrated approach to policies concerning cultural, biological, geological and landscape diversity to achieve a balance between these elements. ${ }^{46}$

Article 9 of the Faro Convention integrates the dimensions discussed above into the sustainable management of the cultural heritage itself. To sustain the cultural heritage, the contarcting parties undertake to promote respect for the integrity of the cultural heritage by ensuring that decisions about change include an understanding of the cultural values involved; define and promote principles for sustainable management, and to encourage maintenance, or ensure that all general technical regulations take account of the specific conservation requirements of cultural heritage. ${ }^{47}$

Article 10 of the Faro Convention establishes continuity between various dimensions of cultural heritage and its economic aspects, corresponding to the multi-dimensionality of the concept of value. In order to make full use of the potential of the cultural heritage as a factor in sustainable economic development, the parties undertake to raise awareness and utilise the economic potential of the cultural heritage; take into account the specific character and interests of the cultural heritage when devising economic policies; and ensure that these policies respect the integrity of the cultural heritage without compromising its inherent values.

\section{h) Shared Responsibility for Cultural Heritage and Public Participation}

Articles 11 to 14 of the Faro Convention raise the necessity for involving all members of society in a rationale of democratic governance in all matters connected with the cultural heritage. In this the governments of parties and of their regions are seen as the leaders of the partnership process. As regards organisation of public responsibilities for cultural heritage, parties undertook to promote an integrated and well-informed approach by public authorities in all sectors and at all levels. ${ }^{48}$ Integration should be understood as comprising that between differ-

46 Art. 8a) and b) of the Faro Convention.

47 Art. 9a), b) and c) of the Faro Convention.

48 Art. 11a) of the Faro Convention.

(c) Palacký University Olomouc, Czech Republic, 2014.

ISSN 1213-8770 (print), ISSN: 2464-6601 (online). 
ent levels of public authorities (local, regional, national), including cross-frontier cooperation, and also that between different policy sectors and domains. State parties should develop the legal, financial and professional frameworks which make possible joint action by public authorities, experts, owners, investors, businesses, non-governmental organisations and civil society. ${ }^{49}$

Very important is an obligation to encourage voluntary initiatives which complement the roles of public authorities ${ }^{50}$ and non-governmental organisations (NGOs) concerned with heritage conservation to act in the public interest. ${ }^{51}$ NGOs promoting the protection of cultural heritage (and meeting any requirements under national law) can provide an effective means of ensuring that the interest of the cultural heritage are represented in administrative or legal proceedings. In order to do so they must have the right to participate. The Convention on Access to Information, Public Participation in Decision-Making and Access to Justice in Environmental Matters (Aarhus, 1998) ${ }^{52}$ give NGOs a similar right in respect of environmental matters.

Article 13 entitled Cultural heritage and knowledge addresses the interface between cultural heritage and the education and training sector. The state parties undertake to facilitate the inclusion of the cultural heritage dimension at all levels of education, not necessarily as a subject of study in its own right, but as a fertile source for studies in other subjects. It deliberately does not provide an exhaustive listing of relevant areas of education and research.

As regard cultural heritage and the information society, the state parties undertake to develop the use of digital technology to enhance access to cultural heritage and the benefits which derive from it, by e.g. encouraging initiatives which promote the quality of contents and endeavour to secure diversity of languages and cultures in the information society, or by supporting internationally compatible standards for the study, conservation, enhancement and security of cultural heritage, whilst combating illicit trafficking in cultural property. Article 14 of the Faro Convention explores the manner in which the rapid development

49 Art. 11b) of the Faro Convention.

50 The third Portorož Declaration (2001) drew attention to the huge potential of willing and able voluntary effort which exists in Europe, which should be mobilised whist avoiding the transfer of responsibilities which properly belongs to state.

51 Art. 11d) and e) and art. 12 of the Faro Convention.

52 The Czech translation of the Aarhus Convention was published in the Czech Collection of International Treaties under No. 124/2004 Coll. See e.g. International and Comparative Law Review, 2013, Vol. 13, Supplement on topic Access to Environmental Information in the EU Member States - Fiction or Reality? The Aarhus Convention was adopted in June 1998 at the Fourth Ministerial Conference of the United Nations Economic Commission for Europe (UNECE) as a part of the "Environment for Europe" process. See DUSíK, Jan: Environmental Democracy and the "Environment for Europe "Process. In: HLAVÁČEK Jiří - KALOUSOVÁ, Magdalena - RENÉOVÁ-MOHN, Markéta - POKORNÝ, Lukáš (Eds.): "Environment for Europe" Process: Success and Chalanges. Prague: Ministry of Environment, 2009, p. $47-54$. 
of digital technologies relates to two objectives of the Faro Convention: access (including democratic engagement) and economic progress. ${ }^{53}$

\section{i) Monitoring and Co-operation}

Articles 15 to 17 of the Faro Convention sets out how the state parties are expected to work together towards the convention's objectives, laying particular stress upon monitoring of progress as the source of priorities for collaborative action. The state parties of the Faro Convention undertake to develop, through the Council of Europe, a monitoring function covering legislations, policies and practices concerning cultural heritage, consistent with the principles established by this convention. Parties should also maintain, develop and contribute data to a shared information system, accessible to the public, which facilitates assessment of how each party fulfils its commitments under the Faro Convention. ${ }^{54}$ Monitoring should be seen primarily as the foundation of dynamic proces for sharing and developing good practice rather than an onerous obligation. To take advantage of modern techniques of information management, and in pursuit of operational efficiency, the Faro Convention takes a different approach to that applied in earlier Council of Europe's conventions. Rather than requiring parties to submit regular reports, the Faro Convention substitutes the requirement to provide input to shared information system, to be managed by the Council of Europe advised by the relevant Steering Committee.

As regards co-operation in follow-up activities, the parties should co-operate with each other and through the Council of Europe. The Faro Convention mentions several forms of cooperation, such as collaborative strategies to address priorities identified through the monitoring proces, multilateral and transfrontier activities and networks for regional co-operation in order to implement these strategies, exchanging, developing, codifying and assuring the dissemination of good practices and informing the public about the aims and implementation of this convention. Any parties of the Faro Convention may, by mutual agreement, make financial arrangements to facilitate international co-operation. ${ }^{55}$

53 LEDIG, Catherine, KLEIN, Aurélie. Some fundamental elements of the legal framework governing cultural heritage protection in the information and knowledge society. Heritage and Beyond. Strasbourg: Council of Europe Publishing, 2009, p. 185 - 190.

54 It is envisaged that the starting points will bet the existing system HEREIN (European Heritage Network). The HEREIN System is a tool to collect data and information related to financing mechanisms, legislations, documentation systems, integrated conservation strategies and awareness-raising actions among others. This data base is complemented by a unique multilingual HEREIN Thesaurus containing over 500 terms and concepts in the 14 languages presently available. This system is available on web page http://www.coe.int/t/ dg4/cultureheritage/heritage/Herein/Default_en.asp.

55 Art. 17 of the Faro Convention. 


\section{Conclusion}

The founding principles of the Council of Europe were directed towards achieving greater unity between its member states by safeguarding and realising the ideals and principles which are their common heritage. Since the European Cultural Convention was opened for signature in 1954 the Council of Europe has pursued a policy of common action to safeguard and encourage the development of European culture and, more particularly, to safeguard and ensure access to the common cultural heritage.

European co-operation in the field of cultural heritage has resulted in a substantial body of texts including specific international conventions, recommendations and guidelines, which have been aimed at technical, scientific, legal and administrative issues.

This paper focuses on the Council of Europe's newest convention in the cultural heritage sector. The Framework Convention on the Value of Cultural Heritage for Society (the Faro Convention) deals with important aspects of heritage as they relate to human rights, and also promotes a wider understanding of heritage and its relationship to community, society and nation. Heritage in itself is not simply a public good; indeed, it has often been a basis for conflict. There is much evidence, in the past and also today, of heritage as a divisive force if it becomes a tool for resistance and the expression of difference.

The Czech Republic does not only have valuable natural resources, but it is also extremely rich in cultural heritage. Contrary to this, however, the Faro Convention has not yet been signed or ratified by the Czech Republic. I personally support an idea that the Czech Republic should become a contracting party of the Faro Convention. The adoption of this international convention would undoubtedly contribute to more effective identification, study, interpretation, protection, conservation and presentation of our cultural heritage.

\section{Bibliography}

ALSTON, Philip, QUINN, Gerard. The Nature and Scope of States Parties Obligations under the International Covenant on Economic, Social and Cultural Rights. Human Rights Quarterly, Vol. 9, No. 2, May, 1987, p. 156-229.

BANDARIN, Francesco. World Heritage - Challenges for the Millenium. 1st edition. Paris: UNESCO World Heritage Centre, 2007.

BLAHOŽ, Josef. Pojem lidských a občanských práv. [The concept of civil and human rights]. In BLAHOŽ, Josef, BALAŠ, Vladimír, KLÍMA, Karel. Ústavní srovnávací právo. 4. vydání. Praha: Wolters Kluwer Česká republika, 2011, s. $177-178$. 
BONNICI, Ugo Mifsud. The human right to the cultural heritage - The Faro Convention's contribution to the recognition and safeguarding of this human right. Heritage and Beyond. Strasbourg: Council of Europe Publishing, 2009, p. 53-58.

DOLFF-BONEKÄMPER, Gabi. Dividing lines, connecting lines Europe's cross-boarder heritage. Strasbourg: Council of Europe Publishing, 2005.

European cultural heritage - Volume I, Intergovernmental co-operation: collected texts. Strasbourg: Council of Europe Publishing, 2003.

HLAVÁČEK, Jiří, KALOUSOVÁ, Magdalena, RENÉOVÁ-MOHN, Markéta, POKORNÝ, Lukáš (Eds.): „Environment for Europe” Process: Success and Challenges. Prague: Ministry of Environment, 2009.

KYSELKA, Igor: Co pro nás vyplývá z přijetí Evropské úmluvy o krajině? [What follows for us from the adoption of the European Landscape Convention?]. Urbanismus a uzemní rozvoj č. 3/2001, s. 25-32.

LEDIG, Catherine, KLEIN, Aurélie. Some fundamental elements of the legal framework governing cultural heritage protection in the information and knowledge society. Heritage and Beyond. Strasbourg: Council of Europe Publishing, 2009, p. 185-190.

MARINGELE, Sarah. European Human Law Rights. The work of European Court of Human Rights illustrated by an assortment of selected cases. Hamburg: Anchor Academic Publishing, 2014.

MEYER-BISCH, Patrice. On the "right to heritage" - The innovative approach of Articles 1 and 2 of the Faro Convention, Heritage and Beyond. Strasbourg: Council of Europe Publishing, 2009, p. 59-68.

PICKARD, Robert. European Cultural Heritage, Vol. II. Rewiev of Policies and Practice. Strasbourg: Council of Europe Publishing, 2002.

POLÁKOVÁ, Jana (ed.): Mezinárodní dokumenty o ochraně kulturního dédictví. Svazek I. [International documents on the protection of cultural heritage. Vol. I.]. Praha: Národní památkový ústav, 2007.

STENOU, Katérina (ed.). UNESCO Universal Declaration on Cultural Diversity. Cultural Diversity Series No. 1, Paris: UNESCO, 2002.

ŠIŠKOVÁ, Naděžda.: Dimenze ochrany lidských právv Evropské unii. [Dimension of human rights protection in the European Union]. Druhé aktualizované a rozšířené vydání, Linde, Praha, 2008.

ŠTURMA, Pavel. Mezinárodní a evropské kontrolní mechanismy v oblasti lidských práv. [International and European control mechanisms in the field of human rights]. 2. vydání. Praha: C. H. Beck, 2003. 
ŠTURMA, Pavel. Úvod do evropského práva ochrany lidských práv. [Introduction to European law of protection of human rights]. Praha: Katedra mezinárodního práva Právnické fakulty Univerzity Karlovy, 1994.

THÉROND, Daniel. Benefits and innovations of the Council of Europe Framework Convention on the Value of Cultural Heritage for Society. Heritage and Beyond. Strasbourg: Council of Europe Publishing, 2009, s. 9 - 12.

ZÁSTĚROVÁ, Jana: Ochrana životního prostředí v činnosti Rady Evropy. [Environmental protection in the activities of the Council of Europe]. České právo životního prostř̌edí, 2001, roč. I, č. 1, s. 45 - 51 .

\section{Acknowledgement:}

The paper has been prepared with support of project No DF11P01OVV019 Methods and tools of landscape architecture for spatial development, which meets thematic priority TP 1.4. of the Program of applied research and development of the national and cultural identity, financed by the Ministry of the Culture of the Czech Republic. 